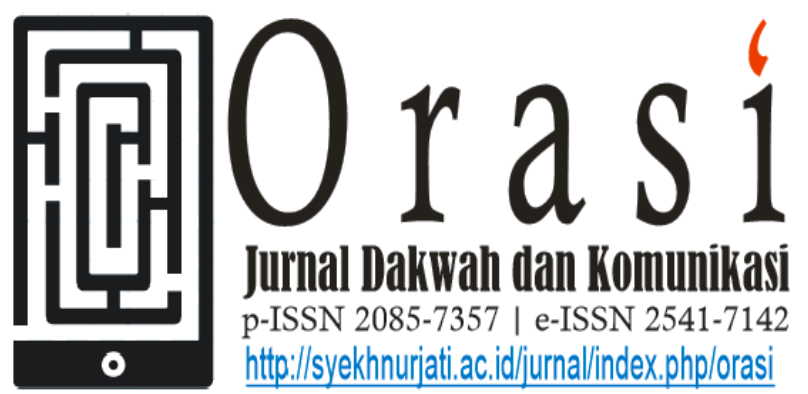

Volume 9 No. 2, PP 59 - 74; November 2018

\title{
KOMUNIKASI ISLAM DAN INTERAKSI MEDIA SOSIAL
}

\author{
Cartono \\ Dosen Jurusan Komunikasi dan Penyiaran Islam \\ Fakultas Ushuluddin Adab dan Dakwah IAIN Syekh Nurjati Cirebon \\ cartonopr@gmail.com
}

\begin{abstract}
ABSTRAK
Saat ini tidak dapat lagi di pungkiri bahwa hampir setiap aktivitas seseorang mulai dari anak-anak, remaja, sampai kalangan orang-orang tua sudah pasti telah mengenal media sosial seperti facebook, twitter, instagram, bbm, path, dsb. media sosial cukup banyak menyumbang dampak positif bagi kehidupan masyarakat, tetapi juga bisa berdampak negatif apabila penggunanya terlalu berlebihan. Komunikasi dalam media sosial kini keberadaan menjadi sangat kompleks. Dua aspek komunikasi melebur menjadi satu. Dimana Komunikasi interpersonal melebur dengan komunikasi massa. Pada saat orang mengunggah sesuatu, dan terjadi interaksi dengan pihak lain, maka komunikasi interpersonal terjadi, dan disaat itu juga terjadi komunikasi massa, karena apa yang diunggah bisa langsung terlihat dan menjadi konsumsi khalayak publik. Dengan kenyataan bahwa apa yang seharusnya berada dalam ruang pribadi kini bisa dikonsumsi publik, maka dari itu kehadiran media sosial kiranya perlu diperhatikan lagi. Bukan untuk menghentikan perkembangannya, agar menjadi efektif. Kesadaran diri setiap pengguna penting untuk ditingkatkan dan keberadaan ajaran agama sebaiknya digunakan, mengingat apa yang diunggah akan bisa mempengaruhi citra diri, dan apa yang diunggah bisa berpengaruh pada hubungan yang terjalin dengan pihak lain Kebebasan berpendapat, keleluasaan berbagi yang ditawarkan media sosial hendaknya bisa disikapi secara bijak oleh penggunanya.
\end{abstract}

Kata kunci: Komunikasi Islam, interaksi, media sosial 


\section{PENDAHULUAN}

Latar Komunikasi merupakan aktifitas dasar manusia. Melalui komunikasi manusia dapat saling berhubungan satu sama lain baik dalam kehidupan seharihari di rumah ditempat kerja, pasar, masyarakat, atau dimanapun manusia berada. Tidak ada manusia yang tidak terlibat dalam komunikasi. Komunikasi begitu sangat penting dalam kehidupan manusia, karena harus diakui bahwa manusia tidak bisa hidup tanpa komunikasi karena manusia adalah makhluk sosial yang saling membutuhkan satu sama lain, dengan berkomunikasi secara efektif maka, kegitan-kegitan yang sering dilakukan manusia bisa berjalan dengan baik. Tanpa adanya komunikasi dengan baik mengakibatkan ketidak teraturan dalam melakukan kegiatan sehari-hari baik itu di rumah maupun dalam suatu organisasi, perusahaan dan dimanapun manusia itu berada. Komunikasi terjadi dimana-mana dengan tujuan berbeda pula. Seperti dalam sebuah kelompok, organisasi, keluarga, antara dua orang ataupun komunikasi di dalam diri sendiri. Macam-macam komunikasi ini memiliki tujuan yang berbeda pula. Namun tujuan utama dari terjadinya komunikasi yaitu tersampaikannya pesan dari pengirim kepada penerima. Pesan itu baik berupa informasi maupun bujukan. Pengiriman pesan tersebut dilakukan melalui bermacam-macam cara dan alat. Melalui mulut ke mulut maupun menggunakan media atau dengan kata lain secara tertulis maupun lisan.

Keberadaan Teknologi diera modern berkembang dengan sangat pesat. Munculnya media digital berbentuk media sosial turut serta mengubah perilaku masyarakat dalam kaitanya berinteraksi dan berkomunikasi. Dilain sisi, tidak ditampik bahwa berbagai bentuk media digital berbasis media sosial itu juga memberikan manfaat bagi masyarakat, sebab memudahkan masyarakat dalam saling berinteraksi dan berkomunikasi secara intens dan cepat tanpa terhalang waktu dan jarak. Dan membuat ikatan persaudaraan menjadi semakin dekat. Namun selain itu juga, media digital berbentuk media sosial ternyata juga menimbulkan dampak negatif. munculnya peredaran berbagai macam berita hoax, kebencian, permusuhan, fitnah telah sangat meresahkan masyarakat dan hal ini dapat menyebabkan disharmoni dan disintegrasi hubungan di dalam masyarakat kita.

Fenomena media sosial di tengah zaman yang penuh inovasi teknologi komunikasi di dunia maya sangat berperan dalam aktivitas keseharian bersosial di masyarakat. Perkembangan teknologi komunikasi di ranah global saat ini sangat pesat. Perubahan ini tentunya 
memberikan dampak yang signifikan di berbagai bidang seperti sosial, ekonomi, pendidikan, dan bidang - bidang yang lainnya. Orang-orang berhak mengeluarkan pendapatnya dimana saja, dimasyarakat luas bahkan disosial media.

\section{A. Kajian Teoritis/ Konsep}

Istilah Komunikasi dalam bahasa inggris communication berasal dari bahasa latin communication, dan bersumber dari kata communis yang berarti "sama". Sama disini maksudnya sama makna. Diasumsikan, jika ada dua orang yang terlihat dalam komunikasi, misalnya dalam bentuk percakapan, maka komunikasi akan terjadi atau berlangsung selama ada kesamaan makna mengenai apa yang dipercakapkan. Kesamaan bahasa yang digunakan dalam percakapan itu belum tentu menimbulkan kesamaan makna. Dengan kata lain perkataan, mengerti bahasanya saja belum tentu mengerti makna yang dibawakan oleh bahasa itu. Jelas percakapan yang dibawa oleh kedua orang tadi dapat dikatakan komunikatif apabila kedua-duanya, selain mengerti bahasa yang dipergunakan, juga mengerti makna dari bahasa yang dipercakapkan.

Aktivitas Komunikasi, harus mengandung kesamaan makna antara dua pihak yang terlibat. Karena kegiatan komunikasi tidak hanya informative, yakni agar orang lain mengerti dan tahu, tetapi juga persuasif, yaitu agar orang lain bersedia menerima satu paham keyakinan, melakukan suatu perbuatan atau kegiatan dan lain-lain. Komunikasi pada dasarnya bersifat instrumental dan persuasif, kita berkomunikasi untuk mengajak baik itu orang lain dan sebenarnya bisa juga berkomunikasi dengan diri sendiri. Ketika kita ingin melakukan suatu hal yang menjadi dilemma bagi kita, kita akan berusaha mempertimbangkan apa tindakan yang akan dilakukan, hal terebut juga disebut sebuah komunikasi.

Dalam pengertian khusus komunikasi, Hovland (dalam Effendy) dalam buku Ilmu Komunikasi Teori dan Praktek mengatakan bahwa komunikasi adalah

Proses mengubah perilaku orang lain (communication is the procces to modify the behaviour of other individuals). Jadi dalam berkomunikasi bukan sekedar memberitahu, tetapi juga berupaya mempengaruhi agar seseorang atau sejumlah orang melakukan kegiatan atau tindakan yang diinginkan oleh komunikator, akan tetapi seseorang akan dapat mengubah sikap pendapat atau perilaku orang lain, hal ini bisa terjadi apabila komunikasi yang disampaikan bersifat komunikatif yaitu komunikator dalam menyampaikan pesan - pesan harus benar - benar dimengerti dan dipahami oleh komunikan untuk mencapai tujuan 
komunikasi yang komunikatif. (2001:10)

Pengertian komunikasi juga datang dari Everett M. Rogers yang dipaparkan oleh Cangara dalam buku karyanya Pengantar Ilmu Komunikasi yang mengatakan bahwa komunikasi adalah : "Proses dimana suatu ide dialihkan dari sumber kepada satu penerima atau lebih dengan maksud untuk mengubah tingkah laku mereka". (1998:19) Lebih dalam lagi menurut Ross dalam Pengantar Ilmu Komunikasi karya Mulyana bahwa komunikasi adalah sebagai berikut Suatu proses menyortir, memilih dan mengirimkan symbol.Symbol sedemikian rupa sehingga membantu pendengar membangkitkan makna atau respons dari pikirannya yang serupa dengan dimaksudkan komunikator (2002:33).

Intinya apa yang disampaikan oleh Ross adalah adanya respon balik dari pesan yang disampaikan komunikator agar sama dengan apa yang dimaksud oleh komunikator. Komunikasi sebenarnya belum ada persetujuan antara ahli - ahli sebagai definisi yang paling utama dan disetujui oleh para ahli - ahli tersebut. Komunikasi memiliki banyak versi dari segi definisi. Kemudian, menurut Rogers dan Kincaid pada 1981 dalam Pengantar Ilmu Komunikasi karya Cangara bahwa Komunikasi adalah suatu proses dimana dua orang atau lebih membentuk atau melakukan pertukaran informasi dengan satu sama lain-nya, yang pada gilirannya akan tiba pada saling pengertian yang mendalam (2006:19).

$$
\text { Rogers mencoba meng- }
$$
spesifikasikan hakikat suatu hubungan dengan adanya suatu pertukaran informasi (pesan) dimana ia menginginkan adanya perubahan sikap dan tingkah laku serta kebersamaan dalam menciptakan saling pengertian dari orang - orang yang ikut sera dalam suatu proses komunikasi.

Dari penjelasan diatas, menjelaskan bahwa komunikasi terjadi antara dua orang atau lebih. Proses komunikasi merupakan bentuk dan kegiatan pertukaran pesan atau informasi antara pengirim pesan dan penerima pesan. Pesan yang disampaikan dapat diterima maksud dan tujuannya, sehingga terbentuk adanya kesamaan makna dan pengertian dari pesan yang disampaikan. Dalam proses komunikasi tidak hanya secara satu arah melainkan secara dua arah, yaitu pesan yang disampaikan kepada penerima pesan dapat diterima dan memberikan feedback dari pesan yang disampaikan kepada pengirim pesan. Komunikasi memiliki peranan yang sangat penting dalam kehidupan manusia diseluruh dunia, karena dengan berkomunikasi segala maksud dan tujuan seseorang bisa tercapai. Komunikasi tidak 
hanya menggunakan kata-kata dari mulut saja namun komunikasi pun bisa dilakukan dengan media dan aspek-aspek lain di luar penggunaan kata-kata yang dihasilkan oleh mulut manusia. Media komunikasi sangat berperan dalam mempengaruhi perubahan masyarakat, terlebih lagi dengan kemajuan teknologi seperti sekarang ini dapat mempermudah seseorang dalam melakukan komunikasi seperti halnya handphone saat ini telah dilengkapi dengan teknologi yang canggih dimana handphone bukan lagi sekedar hanya mengirim pesan dan menghubungi, melainkan sekarang handphone juga dijadikan alat yang bisa digunakan untuk melakukan hal apapun, karena sekarang kebanyakan perangkat handphone telah dibekali fitur internet.

\section{Komunikasi Islam}

Islam adalah salah satu agama terbesar di dunia, dimana Islam memberikan panduan atau petunjuk yang gamblang terhadap komunikasi umatnya di berbagai konteks komunikasi baik itu komunikasi intrapersonal maupun komunikasi interpersonal atau komunikasi antarpribadi serta komunikasi organisasi ataupun juga komunikasi massa. Sejauh ini lebih banyak dunia barat menjadi rujukan kajian komunikasi manusia. Sebelum masuk pada tahap dengan apa yang dimaksud dengan komunikasi Islam, sebaiknya kita kembali ke belakang sehubungan dengan pengertian komunikasi. secara terminologi komunikasi berasal dari bahasa communicare yang artinya "untuk membuat kesamaan" atau "untuk berbagi". Dalam bahasa Latin disebut communication atau communis yang berarti "sama" (Pearson dkk, $2000: 10$ ).

Sedangkan istilah komunikasi dalam bahasa Arab disebut dengan tawashul. Kata Tawashul asal katanya adalah "washala" yang artinya“"sampai”. Dengan demikian, arti kata tawashul merupakan proses pertukaran informasi oleh dua pihak sehingga pesan yang disampaikan bisa dipahami oleh keduanya bagi komunikator. Istilah lain dalam bahasa Arab adalah ittishal yang menekankan pada makna ketersambungan pesan. Pada ittishal, kalau pesan yang dikirimkan tersampaikan dan bersambung pada komunikan/komunikate, maka itulah yang disebut komunikasi dan tidak perlu terjadi feedback atau umpan balik. Menurut peneliti psikologi Raymond S. Ross mengartikan komunikasi sebagai berikut : "Komunikasi merupakan suatu proses transaksional yang terdiri dari pemisahan, dan pemilihan dengan lambang secara kognitif, begitu rupa sehingga dapat membantu orang lain guna mengeluarkan dari pengalamannya sendiri arti atau 
respons yang sama dengan yang dimaksud oleh sumber" (Rakhmat, $2001: 3$ ).

Berdasarkan berbagai pendapat diatas mengenai pengertian atau definisi mengenai Islam, pengertian yang dikemukakan oleh Harjani Hefni merupakan yang mewakili semua pendapat diatas. Dimana menurut pendapatnya, Islam berarti tunduk atau menyerahkan diri kepada Allah SWT, damai, serta selamat. Berangkat dari pengertian itu, yang menjadi tujuan Islam adalah damai dan selamat. Sedangkan, sikap menyerahkan diri kepada Allah SWT dan tunduk terhadap segala perintah Allah SWT yang diturunkan kepada Nabi Muhammad SAW yang tercakup dalam Rukun Islam adalah sarana.

Berdasarkan definisi atau pengertian mengenai komunikasi dan Islam disimpulkan bahwa komunikasi Islam merupakan komunikasi yang dibangun berdasarkan prinsip-prinsip Islam yang memiliki roh kedamaian, keramahan, dan keselamatan (Hefni, 2015). komunikasi Islam sebagai ilmu memiliki rujukan utama sebagai pedoman hidup bagi kaum muslimin, yaitu Al Qur'an dan Hadits Nabi Muhammad SAW. Sumber tersebut memberikan karakterisik komunikasi Islam. Selain dari pada itu, kitab-kitab karangan para ulama serta disiplin ilmu lainnya yang turut menyumbang perkembangan ilmu komunikasi islam.
Sebagaimana yang dinyatakan sebelum ini, amalan komunikasi amat sinonim dengan Islam dan terdapat tiga (3) contoh komunikasi yang terdapat dalam Al-Qur'an, yaitu:

a) Komunikasi Allah S.W.T dengan malaikat dan para rasul;

b) Komunikasi para rasul dengan manusia; dan

c) Komunikasi sesama manusia.

Ini menunjukkan bahawa komunikasi bagi seorang Muslim bukan sekadar antara manusia dengan manusia yang lain tetapi melibat dua pihak lagi yang lebih tinggi kedudukannya. Seseorang Muslim itu, akan dipertanggungjawabkan kepada kuasa yang lebih besar iaitu Allah s.w.t dengan bimbingan baginda Rasul. Seseorang Muslim berkomunikasi bukan sekadar untuk menyampaikan maklumat tetapi membawa tanggungjawab sebagai seorang "daie" atau pendakwah yang diwajibkan menyampaikan mesej mengikut kadar keupayaan masingmasing. Tanggungjawab ini menjadikan tugas komunikasi adalah suatu tugas yang penting malah diperlihatkan oleh Rasulullah s.a.w yang menggesa setiap muslim menyampaikan mesej daripada baginda walaupun hanya "satu ayat".

\subsection{Prinsip-Prinsip Komunikasi Islam}


Islam adalah pedoman kehidupan, yang memuat berbagai panduan atau aturan pada semua wilayah komunikasi manusia. Sebabnya, panduan atau petunjuk tersebut patut dijadikan sebagai prinsip-prinsip. Prinsip merupakan sebuah pedoman yang membuat manusia menafsirkan suatu kejadian, serta membuat penilaian mengenai sesuatu lalu memutuskan mengenai bagaimana berekasi pada situasi tersebut. Dalam Sebuah prinsip memiliki 3 bagian, yaitu mengidentifikasi situasi atau kejadian, yang melibatkan sekumpulan normanorma dan nilai-nilai, dan hubungan antara aksi dan konsekuensi yang mungkin. Merujuk pada hal tersebut, Islam menyaapabilan prinsip-prinsip dalam bentuk yang ideal komunikasi sebagai 2 sumber dasar yang disebut dengan Islam Syariah. Berbeda dengan prinsip-prinsip komunikasi yang telah kita kenal sebelumnya, komunikasi Islam memiliki prinsip-prinsip tersendiri. Menurut pendapat Hefni (2015) prinsipprinsip komunikasi Islam terdiri dari 1) Ikhlas 2) Pahala dan dosa 3) Kejujuran 4) Kebersihan 5) Berkata positif 6) Hati, lisan dan perbuatan merupakan satu kesatuan. 7) mendengar lebih banyak daripada berbicara. 8) kesadaran dalam pengawasan, Allah SWT 8) Selektifitas dan validitas. 9) Saling mempengaruhi 10) Keseimbangan 11) Privasi.

\subsection{Komunikasi Efektif dalam Perspektif Islam}

Komunikasi yang efektif baik entah itu komunikasi verbal maupun non verbal menurut perspektif Islam sangat diperlukan untuk menjaga lingkungan dan masyarakat agar tetap damai, tanpa kekerasan, dan harmonis. Naz Muhammad dan Fazle Omer pada communication skills in islamic perspective (2016) mengatakan bahwa prinsip-prinsip komunikasi yang efektif menurut perspektif Islam yang dibagi dalam komunikasi verbal dan komunikasi non verbal. Beberapa prinsip komunikasi verbal yang efektif dalam perspektif Islam adalah 1) penggunaan Intonasi yang lembut 2) memakai kata-kata yang tepat 3) memakai suara yang lemah lembut 4) mampu memahami mental penerima pesan 5) Memahami situasi dan kondisi 6) Menghindari dominasi pembicaraan 7) Hindari mencela pada diskusi.

\section{Pengertian Media Sosial}

Media sosial merupakan media yang didesain untuk memudahkan interaksi sosial bersifat interaktif dengan berbasis teknologi internet yang mengubah pola penyebaran informasi dari sebelumnya bersifat satu ke banyak audiens tetapi sekarang dari banyak audiens ke banyak 
audiens. Utari dalam DevitaMaulida

Choiru Uma mengatakan bahwa:

Media sosial adalah sebuah media online dimana para penggunanya dapat dengan mudah berpartisipasi. Berpartisipasi dalam arti seseorang akan dengan mudah berbagi informasi, menciptakan konten atau isi yang ingin disampaikan kepada orang lain, memberi komentar terhadap masukan yang diterimanya dan seterusnya. Semua dapat dilakukan dengan cepat dan tak terbatas.

\section{Berdasarkan pendapat di atas} dapat dipahami bahwa media sosial adalah sebuah media online yang memudahkan semua orang untuk berpartisipasi. Semua orang bisa untuk saling berbagi informasi, tukar pikiran dan memberikan masukan atas apa yang diterimanya, semua itu bisa dilakukan dengan cepat tanpa terbatas. Penggunaan Media Sosial Menurut Chris Heuer (dalam Yoga Maulana Putra) pendiri sosial media club dan innovator media baru menyatakan bahwa terdapat 4 penggunaan media sosial diantaranya:

\section{Context}

Bagaimana membentuk sebuah pesan atau cerita (informasi) seperti bentuk dari sebuah pesan itu sendiri, penggunaan bahasa maupun isi dari pesan tersebut

\section{Communication}

Cara berbagi cerita atau informasi yang meliputi cara mendengarkan, merespon dengan berbagai cara seperti menambah gambar ataupun pengemasan pesan yang memuat pengguna merasa nyaman dan pesan tersampaikan dengan baik.

\section{Collaboration}

Kerja sama akun atau perusahaan dengan penggunaannya di media sosial untuk membuat hal baik yang lebih efektif dan efisien

\section{Connection}

Pemeliharaan hubungan yang sudah terbina. Bisa dengan melakukan sesuatu yang bersifat berkelanjutan sehingga pengguna merasa lebih dekat dengan sebuah akun maupun perusahaan pengguna media sosial.

\subsection{Jenis-jenis Media Sosial Media}

sosial secara substansial mengubah cara komunikasi antar organisasi, masyarakat, serta individu. Nurudin menjelaskan jenis-jenis dari media jejaring sosial sebagai berikut.

1) Facebook

Facebook bukanlah yang pertama kali namun saat ini, facebook adalah situs yang paling terkenal dan paling banyak 
digunakan oleh orang-orang dimuka bumi ini. Facebook digunakan sebagai tempat untuk mencari teman-teman lama, relasi bisnis, perjualan barang dan bahkan sebagai tempat nongkrong dan main games. Pendapat lain mengatakan bahwa facebook adalah suatu alat untuk membantu orang berkomunikasi lebih efisien dengan teman lama, keluarga, maupun orang-orang baru di kenal. Facebook menawarkan navigasi yang mudah bagi para penggunanya.

Berdasarkan pendapat di atas dapat dipahami bahwa facebook digunakan untuk mencari teman-teman lama, relasi bisnis, perjualan barang dan bermain games. Facebook mempermudah semua orang untuk melakukan sesuatu dengan orang yang jauh darinya.

2) Twitter

Twitter merupakan sebuah situs web yang dimiliki dan dioperasikan oleh twitter. Situs ini menawarkan jaringan sosial berupa mikroblog sehingga memungkinkan penggunanya untuk mengirim dan membaca pesan yang disebut kicauan (tweets). Kicauan adalah teks tulisan hingga 140 karakter yang ditampilkan pada halaman profil pengguna. Kicauan bisa dilihat secara bebas, namun pengirim dapat membatasi pengiriman pesan ke daftar teman-teman mereka saja. Pengguna dapat melihat kicauan penulis lain yang dikenal dengan sebutan pengikut atau follower.

3) Blackberry

Messenger Blackberry adalah perangkat selular yang memiliki kemampuan layanan laman, telepon, sms, menjelajah internet, Blackberry messenger dan berbagai kemampuan lainnya

4) Instagram

Instagram adalah sebuah aplikasi berbagi foto yang memungkinkan pengguna mengambil foto, menerapkan filter digital dan membagikannya ke berbagai layanan jejaring sosial termasuk milik instagram send.

Berdasarkan pendapat di atas dapat dipahami bahwa facebook, twitter, blackberry dan instagram ini menjadi alat alternatif untuk berkomunikasi bagi banyak orang dan mempermudah mereka untuk berinteraksi dengan sesama mereka agar komunikasi mereka bisa berjalan dengan baik dan lancar. Terutama bagi orang yang memiliki kepribadian yang tertutup, pemalu, atau pendiam. Berkomunikasi melalui facebook, twitter, instagram dan blackberry tidak perlu memperlihatkan diri secara fisik, misalnya saling bertatap muka. Apabila ingin menjalin pertemanan dengan orang yang baru dikenal. 


\subsection{Fungsi Media Sosial}

Media sosial merupakan bagian dari sistem relasi, koneksi dan komunikasi, maka seseorang harus menyikapinya dalam kaitannya dengan fungsi-fungsi yang terkandung dalam teori relasi, koneksi dan komunikasi masyarakat. Sikap yang harus dikembangkan terkait dengan fungsi media sosial antara lain:

1) Sarana belajar, mendengarkan dan menyampaikan.

Aplikasi media sosial dapat dimanfaatkan untuk belajar melalui beragam informasi, data dan isu yangtermuat di dalamnya. Pada aspek lain, media sosial juga menjadi saran untuk menyampaikan berbagai informasi kepada pihak lain.

2) Sarana dokumentasi, administrasi dan integrasi

Bermacam aplikasi media sosial pada dasarnya merupakan gudang dan dokumentasi beragam konten, dari yang berupa profil, informasi, reportase kejadian, rekaman peristiwa, sampai pada hasil-hasil riset kajian. Beberapa hal yang bisa dilakukan dengan media sosial, antara lain membuat blog organisasi, mengintegrasikan berbagai link di perusahaan, menyebarkan konten yang relevan sesuai target di masyarakat, atau memanfaatkan media sosial sesuai kepentingan, visi, misi, tujuan, efisiensi dan efektifitas operasional organisasi.

3) Sarana perencanaan, strategi dan manajemen.

Akan diarahkan dan dibawa ke mana media sosial merupakan domain dari penggunaanya. Media sosial di tangan para pakar manajemen dan marketing dapat menjadi senjata yang dahsyat untuk dilancarkan perencanaan dan strateginya. Sarana kontrol, evaluasi dan pengukuran.

Media sosial berfaedah untuk melakukan kontrol organisasi dan juga mengevaluasi berbagai perencanaan dan strategi yang telah dilakukan. Respon publik dan pasar menjadi alat ukur, kalibrasi dan parameter untuk evaluasi. Sejauh mana masyarakat memahami suatu isu atau persoalan, bagaimana prosedurprosedur ditaati atau dilanggar publik, dan seperti apa keinginan dari masyarakat, akan bisa dilihat langsung melalui media sosial.

\subsection{Manfaat dan Mudarat Media Sosial}

Media sosial yang banyak digunakan oleh orang saat sekarang ternyata ada manfaat dan mudarat dari penggunaannya. ICT Watch dalam buku internet sehat menjelaskan efek positif 
dan negatif dari media sosial bagi remaja, efek positif dari media sosial diantaranya:

1) Remaja dapat belajar mengembangkan keterampilan teknis dan sosial yang sangat dibutuhkan di era digital seperti sekarang ini. Mereka belajar bagaimana cara beradaptasi, bersosialisasi, dengan publik dan meneglola jaringan pertemanan.

2) Memperluas jaringan pertemanan. Berkat situs jejaring sosial, remaja jadi lebih mudah berteman dengan orang lain di seluruh dunia, meski sebagian besar diantaranya tidak pernah mereka temui secara langsung.

3) Remaja akan termotivasi untuk belajar mengembangkan diri melalui temanteman yang mereka jumpai secara online, karena disini mereka berinteraksi dan menerima umpan balik satu sama lain.

4) Situs jejarig sosial membuat remaja menjadi lebih bersahabat, perhatian dan empati. Misalnya memberikan perhatian saat ada teman mereka berulang tahun, mengomentari foto, video dan status teman mereka, menjaga hubungan persahabatan meski tidak dapat bertemu secara fisik.
Dapat dipahami bahwa media sosial itu ada manfaat dan mudarat dari penggunaannya, manfaat dari media sosial bagi seseorang yang bisa menggunakannya dengan baik itu ia bisa memperluas pertemanan baik orang baru orang maupun orang yang telah ia kenal, dapat belajar mengembangkan keterampilan teknis dan sosial, motivasi untuk belajar mengembangkan diri. Newmedia (media sosial) memiliki beberapa pengaruh. Berikut pengaruh media sosial dalam beberapa aspek seperti yang ditulis oleh Syaibani:

1) Individu

Pengguna media sosial akan mendapatkan pengaruh besar jika menggunakannya dengan intensitas yang tinggi. Di satu sisi pengguna bisa mengekspresikan segala idea atau gagasan melalui layanan-layanan yang dapat digunakan tanpa ada alasan. Namun disisi lain, seorang menjadi individualis jika menggunakan internet dengan intensitas yang tinggi tanpa bersosialisasi di dunia nyata.

2) Ekonomi

Media sosial menunjang
perkembangan ekonomi melalui e-
commerce atau komersial elektronik.
Media sosial sangat memungkinkan
adanya ruang pemasaran dan marketing.


Selain itu akses mendapatkan material atauh bahan pun akan lebih luas dan mudah. Namun disisi lain internet juga dapat mengubah perilaku masyarakat.

\section{3) Politik}

Internet telah memunculkan istilah baru yakni Electronic democrac, (Haward dalam Syabiani, 2011:25) menyampaikan bahwa internet merupakan komponen baru dalam sistem komunikasi politik. Website yang digunakan untuk menyampaikan ideide dari pada pilitikus, kepengurusan dan adanya ruang diskusi terbuka dari bawah ke atas dan sebaliknya dari atas ke bawah juga. Ruang diskusi inilah yang memberikan nilai demokratis dalam komunikasi politik.

\section{4) Perubahan sosio-kultura}

Perubahan pola komunikasi ini juga dapat mempengaruhi perubahan pada pola interaksi masyarakat yang beralih dari bentuk nyata (fisik) menjadi nyata.dapat dipahami bahwa media sosial itu bisa untuk mengeluarkan ide-ide dan gagasan, dan melalui media seorang juga bisa memasarkan suatu barang dengan menggunakan media sosial, ia bisa mendapatkan penghasilan tambahan.

Sedangkan efek negatif dari media sosial diantaranya:
1) Remaja menjadi malas belajar berkomunikasi di dunia nyata tingkat pemahaman bahasa pun menjadi terganggu. Jika anak terlalu banyak berkomunikasi di dunia maya, maka pengetahuan tentang seluk-beluk berkomunikasi di kehidupan nyata seperti bahasa tubuh dan nada suara menjadi berkurang.

2) Situs jejaring sosial akan membuat remaja lebih mementingkan diri sendiri. Mereka menjadi tidak sadar akan lingkungan sekitar mereka, karena kebanyakan

mereka menghabiskan waktu di internet. Hal ini mengakibatkan remaja menjadi kurang berempati di dunia nyata.

3) Tidak ada ejaan dan tata bahasa di situs jejaring sosial. Hal ini akan membuat remaja sulit membedakan antara berkomunikasi di situs jejaring sosial dan di dunia nyata.

4) Situs jejaring sosial adalah lahan subur bagi predator untuk melakukan kejahatan. Kita tidak akan pernah tahu apakah seseorang yang baru dikenal remaja di internet, menggunakan jati diri yang sesungguhnya. 
Berdasarkan pendapat di atas dapat dipahami bahwa ternyata media sosial itu juga memberikan dampak negatif bagi penggunanya, yaitu komunikasi dan interaksinya kurang terjalin, karena ia lebih mementingkan media sosial ada pada saat ini. Media sosial juga bisa menjadi predator untuk orang melakukan kejahatan, dan lebih mementingkan dirinya sendiri dari pada orang lain.

\section{METODOLOGI PENELITIAN}

Metode dalam penulisan jurnal ini adalah Metode Penelitian Resepsi dalam penelitian ini menunjukkan adanya polapola pemaknaan kultural yang beragam yang ada pada diri pemirsa terhadap suatu teks, di mana munculnya kultural yang mulivaset pada seseorang memiliki kecederungan yang kuat dalam mempengaruhi pemaknaan terhadap suatu teks. Apabila dihubungkan dengan beberapa kategori konsep identitas kultural maka dapat dilihat bagaimana audiens lalu mendefinisikan teks tersebut sesuai dengan perspektif kultural mereka sendiri. Dalam Temuan tersebut sejalan dengan teori respon pembaca Stanley Fish (dalam Littlejohn,2002:190). Menurut Fish makna tersebut berada pada sisi pembaca dengan mekanisme lalu dikenal sebagai teori respon pembaca. Teks menstimulasi pembaca aktif, namun pada diri pembaca itu sudah terkandung makna, dan interpretasi yang bergantung pada teks tersebut.

\section{HASIL DAN PEMBAHASAN}

Banyak Cendikiawan Nusantara gundah akan kondisi umatnya yang kian jauhnya menerapkan nilai-nilai agama (Islam) dalam kehidupanya. Keresahan tersebut tercermin dari salah satu ahli tafsir Indonesia, prof. Quraish Shihab. Selain lewat dakwah ceramah, perasaan tersebut juga ada dalam bentuk tulisan. Prof. Quraih Shihab telah menulis sebuah buku dengan judul Yang Hilang Dari Kita, Akhlak. Dimana pada isi pengantarnya, ulama yang menjadi salah satu sepuh Nusantara itu menuturkan bahwa moral yang telah diajarkan serta dipraktikkan oleh leluhur bangsa, sama halnya dengan diajarkan oleh agama, kini terabaikan dalam kehidupan keseharian masyarakat. Kritik yang ditujukan bagi seluruh bangsa ini seharusnya dapat menjadikan penyadaran bahwa etika, akhlak sering diabaikan. Kini ruang-ruang privat, bahkan publik sekalipun telah dipenuhi oleh hasrat buas kebencian, mengumbar aurat, dan mematikan karakter orang lain. Inilah yang disebut dengan minus etika sebuah kata yang tepat dalam mengungkapkan realitas kekinian masyarakat. Keadaan tersebut semakin menghawatirkan manakala kita 
mengamati perkembangan paling mutakhir. Dimana keberadaan media sosial (medsos) yang seharusnya menjadi wadah dalam mempererat tali silaturahmi, berbagi pengalaman dan berita yang mencerahkan serta menyejukkan, kini digunakan secara sembarangan bahkan dalam ruang politik. ini merupakan persoalan nasional yang berpotensi memicu konflik politi dan keagamaan hingga memicu perpecahan nasional.

Sebagai umat mayoritas, atas persoalan tersebut Islam dan kaum muslim memiliki Tanggung jawab dalam terlibat aktif menemukan solusi sampai tuntas. Terlebih lagi bahwa Islam merupakan ajawan yang sempurna, yang menyentuh semua aspek kehidupan, dalam hal ini termasuk mengenai bagaimana cara atau adab bermedia. Pada keadaan seperti ini, diperlukan panduan secara tegas dari kalangan agamawan dan pemerintah. Secara tegas, bahwasanya ajaran Islam sehubungan dengan etika bermedia telah ada. adapun etika yang dimaksud. Pertama, tabayyun ( proses cek dan ricek). Ajaran islam tidak menolak terhadap perkembangan teknologi. Dimana dalam Quran Surah Al-Hujarat ayat 6 disebutkan mengenai pedoman mengenai seperti apa etika serta tata cara menyikapi sebuah berita. Disisi lain Popularitas keberadaan laman sosial
Facebook, Twiter dan lainnya dapat menjadi wadah usaha guna membangunkan jaringan. Ini memberi satu alternatif baru dalam interaksi dan komunikasi melalui ruang maya. kemunculan media tersebut dapat menjadi sebagai satu wadah penting guna sebagai media berdakwah dalam kalangan masyarakat. Menurut Sohirin (2008), usaha dakwah melalui Internet perlu diberi keutamaan berbanding penggunaan media tradisional. Ini dikarenakan penyampaian pesan dakwah itu dapat mencapai semua lapisan masyarakat khususnya.

Interaksi sosial merupakan bagian ajaran islam yang sangat diperhatikan dan ditekankan sebab kompleks dan komprehensif. Sangatlah wajar ketika Rasulullah bersabda bahwa beliau diutus ke muka bumi guna menyempurnakan akhlak manusia. Dalam islam melarang umatnya untuk memutuskan hubungan social hal ini sesuai dengan hadits diriwayatkan Bukhari dan Muslim, Rasulullah SAW bersabda bahwa tidak masuk surga bagi orang yang memutuskan silaturahim. Terkait keberadaan media social sendiri, salah satu ayat sering digunakan adalah Surat Al-Hujurat ayat 13 


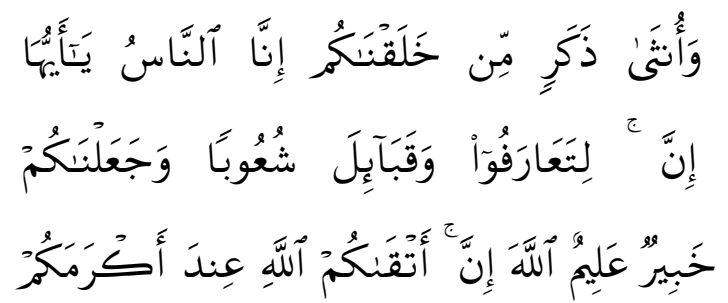

Hai manusia, sesungguhnya Kami menciptakan kamu dari seorang laki-laki dan seorang perempuan dan menjadikan kamu berbangsa - bangsa dan bersukusuku supaya kamu saling kenal-mengenal. Sesungguhnya orang yang paling mulia diantara kamu disisi Allah ialah orang yang paling taqwa diantara kamu. Sesungguhnya Allah Maha Mengetahui lagi Maha Mengenal.”

Dengan adanya media social, maka perbedaan-perbedaan yang ada di masyarakat sebagaimana disebutkan dalam surat al-Hujurat ayat 13 dapat berbaur, bersatu dan menciptakan kesejahteraan dan kemaslahatan bersama."Sesungguhnya orang yang paling mulia diantara kamu disisi Allah ialah orang yang paling taqwa diantara kamu." Dari Potongan ayat diatas hubunganya media social bisa diinterpretasikan sebagai penekanan dan penegasan pada interaksi social yang mesti disertai dengan ketaqwaan. Karena taqwa menjadi etika, aturan, batasan, dan prinsip dalam kegiatan praktek berinteraksi social. Sehingga upaya dalam memediasi perbedaan social senantiasa selalu dilandaskan atas ketaqwaan. Selain itu terkait dampak yang diakibatkan oleh media social yang bersifat positif dan juga negative, merujuk pada dalil di atas maka yang menjadikan baik tidaknya media social bukanlah berdasarkan hasilnya apakah positif atau negative akan tetapi atas dasar proses dan prakteknya dilandasi dengan ketaqwaan ataukah tidak. Dengan demikian apabila yang dipermasalahkan prosesnya, maka secara langsung yang menjadi permasalahan merupakan subjek atau pelaku dalam melakukan proses tersebut itulah yang menjadi faktor penentu sesuatu itu baik atau tidak suatu tindakan.

Komunikasi Islam berfokus terhadap teori-teori komunikasi yang dikembangkan cendikiawan Muslim. Adapun tujuan akhirnya dapat menjadikan komunikasi Islam menjadi sebuah sebagai komunikasi alternatif, terutama dalam menjunjung tinggi nilai-nilai kemanusiaan yang berbanding lurus sesuai dengan fitrah penciptaan manusia. Kesesuaian nilai-nilai komunikasi dengan dimensi penciptaan fitrah kemanusiaan itu memberi manfaat terhadap kesejahteraan masyarakat. Sehingga pada akhirnya pada perspektif ini, komunikasi Islam adalah proses penyampaian atau tukar menukar informasi yang memakai prinsip dan 
kaedah komunikasi yang sesuai dengan Alquran.

\section{PENUTUP}

Terkait dampak yang ditimbulkan oleh media sosial yang terkadang positif dan juga negative, berdasarkan dalil di atas maka yang menentukan baik tidaknya media social yang dilakukan bukanlah berdasarkan hasilnya apakah positif atau negative melainkan berdasarkan proses dan praktek pelaksanaannya yang menggunakan ketaqwaan atau tidak. Dengan demikian, apabila yang dipermasalahkan adalah prosesnya, maka secara langsung yang dipermasalahkan adalah subjek atau pelaku yang melakukan proses tersebut yang menjadi faktor penentu sesuatu itu baik atau tidak. Meski media social sebagai bagian media komunikasi dalam pandangan Islam diperbolehkan sebaiknya masyarakat dalam prakteknya harus disertai dan didasari oleh ketaqwaan yang tentu saja dalam hal ini mesti dilakukan oleh subjek media sosial. sejatinya komunikasi adalah wujud dari kehidupan manusia. Dalam proses komunikasi perlu memperhatikan etika-etika secara baik guna komunikasi tersebut dapat berjalan dengan lancar dan efektif. Dengan harapan apa yang disampaikan lewat media sosial dapat diterima dan direspon dengan baik. Adapun Etika-etika tersebut meliputi perkataan yang benar, lemah lembut, ringan dan mudah dipahami.

\section{DAFTAR PUSTAKA}

Hefni, Harjani. 2015, Komunikasi Islam. Jakarta: Prenadamedia Group

Jensen, Klaus Bruhn, “ News as Social Resources," Dalam European Journal of Communication 3. 3 : 275-301, 1988

Littlejohn, Stephen W. Theories of Human Communication.(7ed.)USA: Wadworth, 2002.

Pearson, Judy C. \& Paul E. Nelson, (2000) Understanding and Sharing: An Introduction to Speech Communication, Dubuque, Iowa: Wm. C. Brown,

Rakhmat, Jalaludin, (2001) Psikologi Komunikasi, Edisi Revisi, Bandung: ,PT.Remaja Rosda. Karya.

Cangara, Hafied.2002.Pengantar Ilmu Komunikasi.Jakarta : $\quad$ PT. RajaGrafindo. Persada.

Effendy, Onong Uchjana.2001. Ilmu Komunikasi Teori dan Praktek. Bandung : PT. Remaja Rosdakarya .

Moleong, Lexy J, Metodologi Penelitian Kualitatif, Bandung: PT Remaja Rosdakarya, Cet. IX, 1998.

Devita Maulida Choiru Uma," Media Sosial dan Perkembangan Fashion Hijab,"Jurnal Komunikasi hal.9 (akses 24 Oktober 2018)

Suharsimi Arikunto, Prosedur Penelitian Suatu Pendekatan Praktik, Jakarta: Rineka Cipta, 2011

Sisrazeni," Hubungan Penggunaan Media Sosial Dengan Interaksi Sosial Mahasiswa Jurusan Bimbingan Konseling Tahun 2016/2017 Iain Batusangkar. 2nd International Seminar on Education 2017 Empowering Local Wisdom on Education for Global Issue hal.3 (akses 24 Oktober 2018) 